contributions to botanical science stands to his name in the transactions of botanical societies and journals as well as in the Government publications of India and Mesopotamia. The practical aspect of his work in relation to the propagation of plants and the combating of plant-diseases in India, in Mesopotamia, and in Great Britain has been widely recognised.

\section{The Chinese Mitten Crab}

The Chinese mitten (or woolly-hand) crab, Eriocheir sinensis (see NATURE, June 9, p. 855), was transported to Germany from China in some unknown way and was first caught in the Aller (a tributary of the Weser) in 1912, but was not identified until 1923. It has spread widely in the river systems of Germany - the Elbe, Weser, Rhine and Oder. It is stated that about 700,000 of these crabs were caught in 1931 at Hamburg; the crab has in fact become a pest in some places. The adult crabs wander down the rivers at the beginning of the breeding season; pairing takes place in brackish water of the lower Elbe and Weser, but the crabs bearing eggs are found off the river estuaries in more saline water. In the interests of controlling the crab, Dr. W. Wolterstorff, of the Magdeburg Museum, has addressed questions to the Peking Society of Natural History. These and the answers are contained in the Bulletin of the Society, vol. 8, Part 3, March 1934. Dr. Wolterstorff refers to a report that the crabs were cleared out of the lower Liang Ho River about twenty years ago with nets, as they destroyed the fish, and asks if this was successful. $\mathrm{He}$ directs attention to the statement of Prof. Lu-fong of Tientsin that the Chinese consider the crabs holy and hence the crabs caught are not eaten but burnt, and points out that this is at variance with the statement of Marquard that the crab is a popular item of food in China. In reply to the questions, Y. T. Mao, of the Department of Biology, Yenching University, states that Eriocheir sinensis is one of the edible crabs commonly found along the coastal provinces of China and that the Chinese do not consider the crab holy. He adds that according to his observation it is not necessary for the crab to lay its eggs in salt water and that he has not heard that the crabs had to be cleared out from a river at Tientsin, nor has he heard of any river in China inhabited by such a large number of crabs as were stated to occur in the Elbe.

\section{Will the Chinese Mitten Crab Invade British Waters?}

The Ministry of Agriculture and Fisheries has issued a notice (Fisheries Notice, No. 22, June 1934) on this crab, pointing out that it "would in no wise be a welcome addition to the British fauna". During its migrations, particularly upstream, the crab tunnels into river banks and the wash of water in these burrows is liable to cause subsidence and hence serious damage to the banks. Further, the erab is varacious; it clears bait from lines and eats the fish taken thereon, and bites through nets and lines. The note suggests that a careful watch should be kept for this crab, especially on the east coast of Great
Britain; its destruction at all possible times might at least assist in restricting the numbers of this unwanted invader.

\section{Science and Social Problems}

IN a lecture on "The Man of Science and the Science of Man" delivered at the University of Liverpool on December 7, a copy of which reached us recently, Prof. J. L. Myres discusses the responsibility of science for social disorder. Much of the current confusion of thought in this matter he attributes to the common failure to distinguish discovery from invention, and, more dangerous still, the engineer or inventor from employers or exploiters who require an immediate solution of a particular practical problem in applied science for their own purpose. The man of science has an individual moral responsibility for the full use of his specific powers in investigating Nature and rationalising the world around him, and the growth of personal responsibilities, with the concurrent graver risks of personal abuse, provides some of our most serious social and international problems. One of the problems to which thought has not yet been adequately applied in this way is the problem of leisure, which is one with that of unemployment or disemployment through the growth of rationalisation or mechanisation of industry. For this our system of education, and particularly the high degree of specialisation in the training of students of science, are largely to blame and Prof. Myres enters an eloquent plea for expositors of science who are competent to impart to the general community something of the spirit and methods of science, so as to afford them an adequate general scientific background for the life they lead in this highly technical age.

Prof. Myres deals also a hard blow at the slovenliness of the scientific worker in his written communications whether for the specialist or a wider public, particularly his neglect to use current linguistic coin, acceptable at its face value of words or sense. These points in a valuable address may easily be overlooked by the scientific worker in his interest in the subsequent discussion of the clash of cultures in modern life and the way in which a science of man could be of service under modern conditions. A field of scientific research is here visualised, the results of which are potentially applicable to a wide range of everyday problems. There is required, too, the capacity to see life as a whole and not as a series of independent units. The latter tendency, no less than excessive specialisation, are major obstacles to the noble conception of citizenship for which Prof. Myres pleads, and which demands the exercise of freedom in speech, in thought and in life.

\section{National Art Gallery and Museum for New Zealand}

AT the ceremonial laying of the foundation stone of a National Art Gallery and Dominion Museum for New Zealand, at Wellington, on April 14, Lord Bledisloe, Grovernor-General of New Zealand, gave 